\section{Using a scale model room to assess the contribution of building material of volcanic origin to indoor radon}

Carlo Lucchetti, Mauro Castelluccio, Matteo Altamore, Alessandra Briganti, Gianfranco Galli, Michele Soligo, Paola Tuccimei (D), Mario Voltaggio

\begin{abstract}
In the frame of Radon rEal time monitoring System and Proactive Indoor Remediation (RESPIRE), a LIFE 2016 project funded by the European Commission, the contribution of building materials of volcanic origin to indoor radon concentration was investigated. First, total gamma radiation and related outdoor dose rates of geological materials in the Caprarola area (Central Italy) were measured to define main sources of radiation. Second, ${ }^{222} \mathrm{Rn}$ and ${ }^{220} \mathrm{Rn}$ exhalation rates of these rocks used as building materials were measured using an accumulation chamber connected in a closed loop with a RAD7 radon monitor. Among others, the very porous "Tufo di Gallese" ignimbrite provided the highest values. This material was then used to construct a scale model room of $62 \mathrm{~cm} \times 50 \mathrm{~cm} \times 35 \mathrm{~cm}$ (inner length $\times$ width $\times$ height, respectively) to assess experimental radon and thoron activity concentration at equilibrium and study the effects of climatic conditions and different coatings on radon levels. A first test was carried out at ambient temperature to determine experimental ${ }^{222} \mathrm{Rn}$ and ${ }^{220} \mathrm{Rn}$ equilibrium activities in the model room, not covered with plaster or other coating materials. Experimental ${ }^{222} \mathrm{Rn}$ equilibrium was recorded in just two days demonstrating that the room "breaths", exchanging air with the outdoor environment. This determines a dilution of indoor radon concentration. Other experiments showed that inner covers (such as plasterboard and different kinds of paints) partially influence ${ }^{222} \mathrm{Rn}$ but entirely cut the short-lived ${ }^{220} \mathrm{Rn}$. Finally, decreases in ambient temperature reduce radon exhalation from building material and, in turn, indoor activity concentration.
\end{abstract}

Keywords: Building materials • Indoor radon • Indoor thoron $\bullet$ Model room $\bullet$ Natural radiation $\bullet$ Radon and thoron exhalation rates

\section{Lucchetti, M. Castelluccio \\ Università "La Sapienza" \\ Dipartimento di Scienze della Terra \\ Piazzale Aldo Moro 5, 00185 Roma, Italy \\ and Università "Roma Tre", Dipartimento di Scienze \\ Largo San Leonardo Murialdo 1, 00146 Roma, Italy}

M. Altamore, A. Briganti, M. Soligo, P. Tuccimei ${ }^{\bowtie}$ Università "Roma Tre", Dipartimento di Scienze

Largo San Leonardo Murialdo 1, 00146 Roma, Italy

E-mail: paola.tuccimei@uniroma3.it

G. Galli

Istituto Nazionale di Geofisica e Vulcanologia

Sezione Roma 1

Via di Vigna Murata 605, 00143 Roma, Italy

M. Voltaggio

Consiglio Nazionale delle Ricerche

Istituto di Geologia Ambientale e Geoingegneria

Area della Ricerca Roma 1, Via Salaria km 29.300,

00015 Monterotondo, Roma, Italy

Received: 20 November 2019

Accepted: 22 January 2020

\section{Introduction}

Human population is continuously exposed to ionizing radiation from several natural sources that can be classified as cosmic or terrestrial contribution. The former is related to high-energy cosmic rays incident on the Earth's atmosphere and the latter to radionuclides in the Earth's crust: mostly uranium and thorium radioactive families together with potassium $\left({ }^{40} \mathrm{~K}\right)$. In most circumstances, radon, a noble gas produced in the radioactive decay of the uranium and thorium progeny, is the major contributor to the total dose [1].

Radon tends to accumulate in indoor environment where it can reach very high levels. The main sources of indoor radon are soil gas, the building materials and tap water, especially when they are enriched in ${ }^{226} \mathrm{Ra}$ and ${ }^{232} \mathrm{Th}$, which are the precursors of main radon isotopes ${ }^{222} \mathrm{Rn}$ and ${ }^{220} \mathrm{Rn}$, respectively [2].

We investigate here the contribution of ${ }^{226} \mathrm{Ra}-$ and ${ }^{232}$ Th-rich building materials of volcanic origin to indoor radon concentration in the frame of Radon rEal time monitoring System and Proactive Indoor Remediation (RESPIRE), a LIFE 2016 project funded by the European Commission. 
Caprarola (Viterbo, Central Italy) is one of the study sites of the project. It stands on a volcanic substrate produced by Vico apparatus. Historical and modern buildings are constructed with ignimbrites and phreatomagmatic products of local provenance. High indoor radon and gamma radiation dose were recorded [3].

As a first part of the study, a total gamma radiation survey in the Caprarola municipality was carried out using several samples of different origins to have an overview of radioactivity distribution and to define its main sources. Second, a database of ${ }^{222} \mathrm{Rn}$ and ${ }^{220} \mathrm{Rn}$ exhalation rates of local building materials was accomplished. Then, we constructed a scale model room with a volume of $\sim 0.110 \mathrm{~m}^{3} \mathrm{using}$ the ignimbrite with the highest ${ }^{222} \mathrm{Rn}$ and ${ }^{220} \mathrm{Rn}$ exhalation rate, in order to investigate the role of different kinds of covers and paints in indoor radon levels.

\section{Study area}

Caprarola town (Central Italy) is located about $50 \mathrm{~km}$ north of Rome, at the edge of Cimini mountains. It stands on a volcanic substrate (lithoid ignimbrites and phreatomagmatic products) emitted 400000 to 100000 years ago by the Vico centre. These materials crop out in the south-eastern sector of the study area, whereas recent lake deposits are located around Vico Lake in the north-western sector of the municipality [3].

Historical and modern buildings at Caprarola are built with these ${ }^{226} \mathrm{Ra}-{ }^{232} \mathrm{Th}$ - and ${ }^{40} \mathrm{~K}$-rich ignimbrites and phreatomagmatic products. High indoor radon (average value of $770 \mathrm{~Bq} \cdot \mathrm{m}^{-3}$ ) and annual effective dose equivalent $\left(\sim 0.85 \mathrm{mSv} \cdot \mathrm{y}^{-1}\right)$ were recorded in the town [3].

\section{Material and methods}

\section{Field work}

Sixteen soil samples of different nature were collected in the municipality of Caprarola (Fig. 1). Sampling location was identified using a GPS. After drying at $100^{\circ} \mathrm{C}$ for $24 \mathrm{~h}$, samples were analysed for total gamma radiation according to the methods described in the following section.

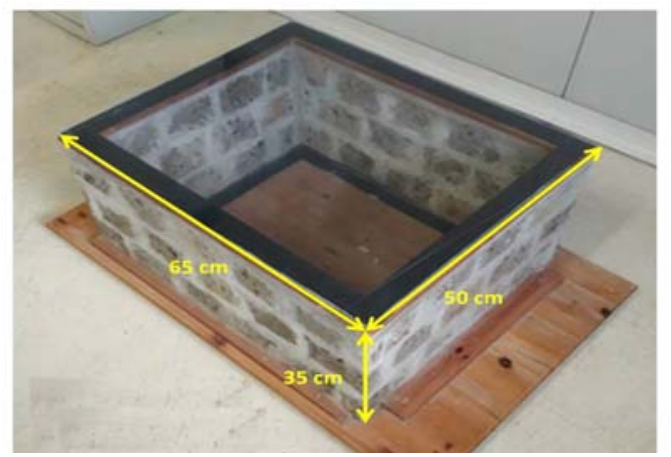

Fig. 1. The scale model room of $62 \mathrm{~cm} \times 50 \mathrm{~cm} \times 35 \mathrm{~cm}$ (inner length $\times$ width $\times$ height), made of "Tufo di Gallese" ignimbrite (Caprarola area, Central Italy).
Furthermore, four different materials were purchased from a building material store in Caprarola. Two of them were lithoid ignimbrites, "Tufo di Gallese" and "Tufo di Riano", nowadays largely employed to construct the buildings, and the others were phreatomagmatic products, "Peperino Grigio di Vitorchiano" and "Peperino Rosato di Bassano in Teverina" used to make steps and thresholds and for decoration. They were analysed for porosity; ${ }^{226} \mathrm{Ra}$, ${ }^{232} \mathrm{Th}$ and ${ }^{40} \mathrm{~K}$ activity concentration and ${ }^{222} \mathrm{Rn}$ and ${ }^{220} \mathrm{Rn}$ exhalation rates.

Finally, $60 \mathrm{~kg}$ of "Tufo di Gallese" ignimbrite was bought later to construct the scale model room.

\section{Equipment and laboratory methods}

Measurements of total gamma radiation were carried out using a digital ratemeter connected to a scintillator of $2^{\prime \prime} \times 2^{\prime \prime}$ (diameter $\times$ length). The ratemeter (model 2241-3, Ludlum Measurements, Inc.) is equipped with a built-in scaler that provides timed counts over a user specified period. The gamma detector (model 44-11, Ludlum Measurements, Inc.) collecting gamma radiation from $60 \mathrm{keV}$ to $2 \mathrm{MeV}$ is optically coupled to a photomultiplier tube of diameter 2". The sensitivity is typically $900 \mathrm{cpm}$ per $0.01 \mu \mathrm{Sv} / \mathrm{h}\left({ }^{137} \mathrm{Cs}\right)$.

In all, $200 \mathrm{~g}$ to $500 \mathrm{~g}$ of dried material was introduced in a Marinelli beaker placed over the gamma scintillator kept in a vertical position, always in the same location in the laboratory. A time of $60 \mathrm{~s}$ was selected as the count time for the determination of gamma radiation of samples, as well as for the measurement of natural background (empty Marinelli beaker, analysed in the same experimental conditions used for soil samples). Each measurement was repeated at least ten times in order to check for data reproducibility and estimate the uncertainty, which was constantly below $2.5 \%$. The net gamma radiation due to analysed materials was obtained by subtracting the background contribution.

The experimental set-up to measure radon and thoron exhalation rates makes use of a RAD7 radon monitor (Durridge Company Inc.) equipped with a silicon alpha detector, in line connected to a $5.1 \mathrm{~L}$ accumulation chamber, located in a thermostatic bath set at $30^{\circ} \mathrm{C}$. The experimental configuration and calibration of this methodology, first presented in [4], is well described in [5].

The building material was previously cut into small blocks $(15 \mathrm{~cm} \times 10 \mathrm{~cm} \times 5 \mathrm{~cm})$ and then dried before the measurement. No desiccant was used during the test, even if drierite $\left(\mathrm{CaSO}_{4}\right)$ was used before the experiment to reduce absolute humidity in the experimental circuit. The ${ }^{222} \mathrm{Rn}$ growth curve and ${ }^{220} \mathrm{Rn}$ average activity concentration in the closed-loop circuit were monitored with a cycle time of $1 \mathrm{~h}$ for $16-18 \mathrm{~h}$ in order to calculate radon and thoron exhalation rates [5]. It is worth stressing that these values were strongly reduced by drying [6, 7], but this condition was necessary to compare emission of different materials. Therefore, values from dried samples were not representative of experimen- 
tal exhalation rates in the model room tests, where materials were humid. Porosity was determined using a helium pycnometer (AccuPyc II 1340) on cubes of $2.5 \mathrm{~cm} / \mathrm{side}$, using a method based on gas displacement and volume/pressure relationship.

${ }^{226} \mathrm{Ra},{ }^{232} \mathrm{Th}$ and ${ }^{40} \mathrm{~K}$ activity concentration was achieved using a gamma-ray spectrometer produced by EG\&G Ortec and equipped with a low-background coaxial HPGe detector. ${ }^{226} \mathrm{Ra}$ was analysed via respective progenies ${ }^{214} \mathrm{Bi}$, at a photopeak of $609 \mathrm{keV} ;{ }^{232} \mathrm{Th}$ by means of ${ }^{228} \mathrm{Ac}$ at a photopeak of $911 \mathrm{keV}$ and ${ }^{40} \mathrm{~K}$ via its peak at $1461 \mathrm{keV}$. ${ }^{226} \mathrm{Ra}$ analysis required an airtight housing and a waiting time of 21 days to reach radioactive equilibrium. Activities were calculated by comparison with a soil standard, counted using the same amount, grain size and geometry as the samples; then, any self-absorption effects were ruled out in the sample/ standard normalization [8].

\section{The scale model room}

"Tufo di Gallese" ignimbrite was cut into 60 blocks $(15 \mathrm{~cm} \times 10 \mathrm{~cm} \times 5 \mathrm{~cm}$ per block $)$ and used to construct a scale model room of $62 \mathrm{~cm} \times 50 \mathrm{~cm} \times$ $35 \mathrm{~cm}$ (inner length $\times$ width $\times$ height). A white cement mortar with a negligible ${ }^{222} \mathrm{Rn}$ and ${ }^{220} \mathrm{Rn}$ exhalation rate was used to glue blocks. Only the walls of the room were made from ignimbrite stone (surface area of $0.78 \mathrm{~m}^{2}$ ). The floor and the roof consisted of Plexiglas boards, with the lower one mounted on a resistant wood table. The total inner volume of the chamber was about $0.110 \mathrm{~m}^{3}$, and the walls' surface area was $0.78 \mathrm{~m}^{2}$ (Fig. 1).

Two taps were mounted on the upper Plexiglas board to connect the room with input and output openings of the RAD7 monitor via vinyl tubing, provided by Durridge Company Inc. A cylinder of desiccant (drierite) was placed before the inlet of RAD7 to reduce air humidity. Indoor air was sampled at the centre of the model room and then transferred to the radon monitor. ${ }^{222} \mathrm{Rn}$ and ${ }^{220} \mathrm{Rn}$ activity concentration was corrected for the effects of water molecules on the electrostatic collection of ${ }^{218} \mathrm{Po}$ ions onto the surface of silicon detectors (neutralization) according to [9]. Initial radon concentration in the model room was reduced down to zero, due to purging with nitrogen gas.

The indoor concentration of ${ }^{222} \mathrm{Rn}$ and ${ }^{220} \mathrm{Rn}$ exhaled from the walls of the model room increased exponentially and tended to an equilibrium value (in $\mathrm{Bq} \cdot \mathrm{m}^{-3}$ ) between exhaled and decayed nuclides. This value depended on the volume of the model room, its exhalation surface, the ${ }^{222} \mathrm{Rn}$ and ${ }^{220} \mathrm{Rn}$ decay constants, ${ }^{222} \mathrm{Rn}$ and ${ }^{220} \mathrm{Rn}$ exhalation rates and time. In case of radon loss out of the model room, the growth of ${ }^{222} \mathrm{Rn}$ in the accumulation chamber followed an exponential trend, where the effective time constant was not the decay constant but depended on the leakage out of the model room and diffusion through the ignimbrite walls. The stronger this exchange, the lower the equilibrium concentration and the shorter the time to reach constant conditions. These processes, as well as temperature and air humidity, obviously affected the value of exhalation rates.

\section{Results}

\section{Dot distribution map of total gamma radiation}

A dot distribution map of mass total gamma radiation (Fig. 2) was obtained using data reported

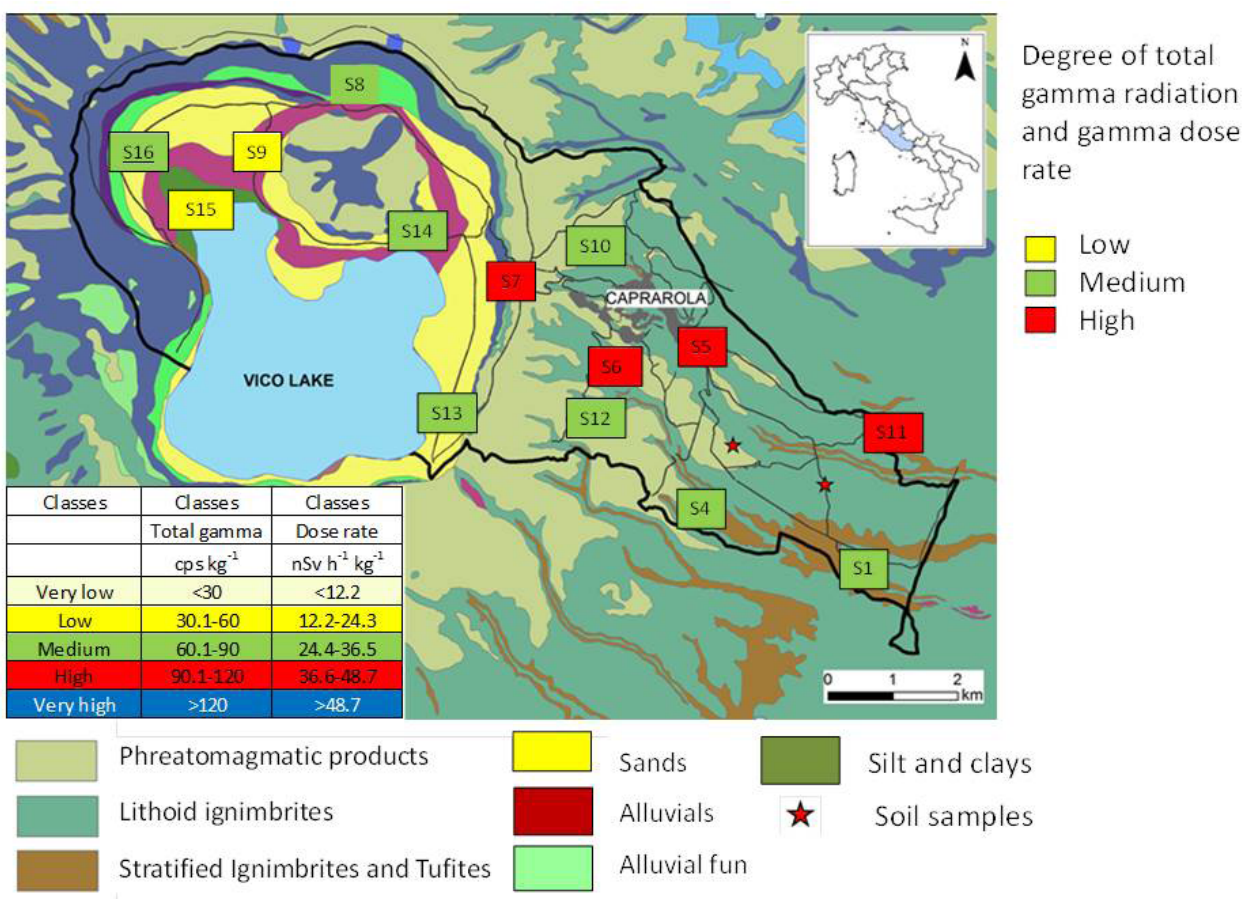

Fig. 2. Dot distribution map of total gamma radiation in the Caprarola area (Central Italy), plotted over a simplified support geological map from [3]. A chromatic scale identifies classes of danger for total gamma radiation and correspondent outdoor gamma dose rate. 
Table 1. Total gamma radiation and outdoor gamma rate of soil samples from the Caprarola area

\begin{tabular}{|c|c|c|c|c|c|}
\hline Samples & Geology & $\begin{array}{c}\text { Total gamma } \\
\text { radiation }\left[\mathrm{cps} \cdot \mathrm{kg}^{-1}\right]\end{array}$ & $\mathrm{SE}_{\text {ave }}$ & $\begin{array}{l}\text { Outdoor dose rate } \\
{\left[\mathrm{nSv} \cdot \mathrm{h}^{-1} \cdot \mathrm{kg}^{-1}\right]}\end{array}$ & $\mathrm{SE}_{\mathrm{ave}}$ \\
\hline 1 & Stratified ignimbrites and tifites & 99.8 & 0.5 & 40.5 & 0.2 \\
\hline 4 & Stratified ignimbrites and tifites & 75.6 & 1.2 & 30.7 & 0.4 \\
\hline 5 & Lithoid ignimbrites & 36.6 & 0.5 & 55.4 & 0.2 \\
\hline 6 & Lithoid ignimbrites & 73.7 & 1.2 & 30.3 & 0.5 \\
\hline 7 & Lithoid ignimbrites & 155.6 & 0.9 & 65.1 & 0.4 \\
\hline 8 & Allvial fans & 73.7 & 0.8 & 29.6 & 0.3 \\
\hline 9 & Alluvials & 55.0 & 0.5 & 22.0 & 0.2 \\
\hline 10 & Phreatomagmatic product & 76.6 & 1.0 & 31.6 & 0.4 \\
\hline 11 & Lithoid ignimbrites & 101.6 & 1.0 & 40.7 & 0.4 \\
\hline 12 & Phreatomagmatic product & 76.8 & 0.5 & 31.2 & 0.2 \\
\hline 13 & Sands & 98.2 & 1.2 & 40.1 & 0.5 \\
\hline 14 & Sands & 35.4 & 0.9 & 14.4 & 0.3 \\
\hline 15 & Silt and clays & 51.7 & 1.3 & 21.2 & 0.5 \\
\hline 16 & Sands & 73.4 & 1.3 & 29.8 & 0.5 \\
\hline
\end{tabular}

Note: $\mathrm{SE}_{\text {ave }}$ is the standard error, expressed as the standard deviation divided by the square root of number of replicates [10].

Table 2. Porosity, ${ }^{232} \mathrm{Th},{ }^{226} \mathrm{Ra}$ and ${ }^{40} \mathrm{~K}$ specific activities and ${ }^{222} \mathrm{Rn}$ and ${ }^{220} \mathrm{Rn}$ exhalation rates $(E)$ of building materials used in the Caprarola area

\begin{tabular}{lccccccc}
\hline \multicolumn{1}{c}{ Samples } & Material & $\begin{array}{c}\text { Porosity } \\
{[\%]}\end{array}$ & $\begin{array}{c}{ }^{232} \mathrm{Th} \\
{\left[\mathrm{Bq} \cdot \mathrm{kg}^{-1}\right]}\end{array}$ & $\begin{array}{c}{ }^{226} \mathrm{Ra} \\
{\left[\mathrm{Bq} \cdot \mathrm{kg}^{-1}\right]}\end{array}$ & $\begin{array}{c}{ }^{40} \mathrm{~K} \\
{\left[\mathrm{~Bq} \cdot \mathrm{kg}^{-1}\right]}\end{array}$ & $\begin{array}{c}E_{222} \\
{\left[\mathrm{~Bq} \cdot \mathrm{m}^{-2} \cdot \mathrm{h}^{-1}\right]}\end{array}$ & $\begin{array}{c}E_{220} \\
{\left[\mathrm{~Bq} \cdot \mathrm{m}^{-2} \cdot \mathrm{h}^{-1}\right]}\end{array}$ \\
\hline Tufo di Gallese & Lithoid ignimbrite & 43 & $290 \pm 5$ & $190 \pm 3$ & $2239 \pm 28$ & $5.91 \pm 0.14$ & $6434 \pm 494$ \\
Tufo di Riano & Lithoid ignimbrite & 50 & $205 \pm 7$ & $115 \pm 4$ & $1576 \pm 43$ & $2.15 \pm 0.13$ & $4223 \pm 278$ \\
Peperino Grigio & Phreatomagmatic product & 19 & $117 \pm 4$ & $102 \pm 2$ & $1158 \pm 19$ & $0.78 \pm 0.16$ & $2655 \pm 332$ \\
Peperino Rosato & Phreatomagmatic product & 18 & $155 \pm 4$ & $117 \pm 2$ & $1273 \pm 12$ & $0.44 \pm 0.19$ & $1632 \pm 199$ \\
\hline
\end{tabular}

in Table 1. Ignimbrites belong to the high total gamma radiation class, phreatomagmatic products to the middle-degree group and other sediments to the low cluster. Corresponding values of external gamma dose rate, referred to the mass unit, are also provided.

\section{Radon and thoron exhalation rates of building materials from the Caprarola area}

To assess radon release from naturally occurring radioactive materials (lithoid ignimbrites and phreatomagmatic products) used to construct and refine buildings in Caprarola, we performed measurements of ${ }^{222} \mathrm{Rn}$ and ${ }^{220} \mathrm{Rn}$ exhalation rates to correlate with porosity and activity concentration of gamma-emitting nuclides (Table 2). Highest values of ${ }^{222} \mathrm{Rn}$ (from approximately $2.2 \mathrm{~Bq} \cdot \mathrm{m}^{2} \cdot \mathrm{h}^{-1}$ to $5.9 \mathrm{~Bq} \cdot \mathrm{m}^{2} \cdot \mathrm{h}^{-1}$ ) and ${ }^{220} \mathrm{Rn}$ (from approximately $4200 \mathrm{~Bq} \cdot \mathrm{m}^{2} \cdot \mathrm{h}^{-1}$ to $6400 \mathrm{~Bq} \cdot \mathrm{m}^{2} \cdot \mathrm{h}^{-1}$ ) exhalation rates characterize very porous (from $43 \%$ to $50 \%$ ) lithoid ignimbrites, while phreatomagmatic products with a lower porosity $(\sim 19 \%)$ show lowest ${ }^{222} \mathrm{Rn}$ (from approximately $0.4 \mathrm{~Bq} \cdot \mathrm{m}^{2} \cdot \mathrm{h}^{-1}$ to $0.8 \mathrm{~Bq} \cdot \mathrm{m}^{2} \cdot \mathrm{h}^{-1}$ ) and ${ }^{220} \mathrm{Rn}$ (from about $1600 \mathrm{~Bq} \cdot \mathrm{m}^{2} \cdot \mathrm{h}^{-1}$ to $2700 \mathrm{~Bq} \cdot \mathrm{m}^{2} \cdot \mathrm{h}^{-1}$ ) exhalation rates. Nonetheless, a weak correlation between porosity and radon (0.67) and thoron (0.80) exhalation rates was determined, as expected, since correlation would be significant only if materials with the same Ra and Th contents and different porosities are evaluated.

Conversely, radon and thoron emissions of lithoid ignimbrites were pretty well correlated with ${ }^{226} \mathrm{Ra}$ and ${ }^{232} \mathrm{Th}$ specific activities (0.95 and 0.92 , respectively).
In particular, "Tufo di Gallese" ignimbrite, displaying the highest ${ }^{222} \mathrm{Rn}$ and ${ }^{220} \mathrm{Rn}$ emission, had the highest ${ }^{232} \mathrm{Th}\left(290 \mathrm{~Bq} \cdot \mathrm{kg}^{-1}\right)$ and ${ }^{226} \mathrm{Ra}\left(190 \mathrm{~Bq} \cdot \mathrm{kg}^{-1}\right)$ activity concentrations, while "Tufo di Riano" ignimbrite with lower ${ }^{222} \mathrm{Rn}$ and ${ }^{220} \mathrm{Rn}$ exhalation rates was characterized by lower ${ }^{232} \mathrm{Th}\left(205 \mathrm{~Bq} \cdot \mathrm{kg}^{-1}\right)$ and ${ }^{226} \mathrm{Ra}$ $\left(115 \mathrm{~Bq} \cdot \mathrm{kg}^{-1}\right)$ contents (Table 2$)$. Finally, it is worth noting that "Peperino Rosato" phreatomagmatic product showed exhalation rates $\sim 60 \%$ lower than those of "Peperino Grigio", which is characterized by a higher ${ }^{232} \mathrm{Th}\left(117 \mathrm{~Bq} \cdot \mathrm{kg}^{-1}\right)$ and ${ }^{226} \mathrm{Ra}\left(102 \mathrm{~Bq} \cdot \mathrm{kg}^{-1}\right)$ activity concentration and a similar porosity (Table 2).

Based on these data, the very porous "Tufo di Gallese" ignimbrite, the strongest radon-emitting (Table 2) and most widely used material in the historical centre of Caprarola, was used to construct the scale model room. Furthermore, it is worth noting that this material extensively crops out in the Caprarola area and is also characterized by the highest total gamma radiation and the associated outdoor dose rate (Table 1 ).

\section{Assessing indoor radon and thoron concentration in the model room}

Five different experiments were then carried out to assess ${ }^{222} \mathrm{Rn}$ and ${ }^{220} \mathrm{Rn}$ activity concentration at equilibrium and study the effects of climatic conditions and different coatings on radon levels. Main results are reported in Table 3 .

The first test was carried out to assess (i) equilibrium levels of ${ }^{222} \mathrm{Rn}$ and ${ }^{220} \mathrm{Rn}$ in the model room with side walls not covered with plaster or other 
Table 3. Experimental equilibrium ${ }^{222} \mathrm{Rn}$ and ${ }^{220} \mathrm{Rn}$ and temperature in the model room

\begin{tabular}{lcccccc}
\hline \multirow{2}{*}{ Parameters } & \multicolumn{5}{c}{ Experiments } \\
\cline { 2 - 7 } & 1 & 2 & 3 & 4 & $5 \mathrm{a}$ & $5 \mathrm{~b}$ \\
\hline $\begin{array}{l}\text { Experimental equilibrium } \\
{ }^{222} \mathrm{Rn}\left[\mathrm{Bq} \cdot \mathrm{m}^{-3} \text { ] }\right.\end{array}$ & $770 \pm 50$ & $10623 \pm 137$ & $13154 \pm 211$ & $12145 \pm 227$ & $11400 \pm 155$ & $1040 \pm 71$ \\
$\begin{array}{l}\text { Experimental equilibrium } \\
{ }^{220} \mathrm{Rn}\left[\mathrm{Bq} \cdot \mathrm{m}^{-3} \text { ] }\right.\end{array}$ & $523 \pm 203$ & $530 \pm 124$ & $230 \pm 103$ & bdl & bdl & bdl \\
Experimental temperature $\left[{ }^{\circ} \mathrm{C}\right]$ & $18-24$ & $20-26$ & $25-31$ & $22-27$ & $23-27$ & $23-27$ \\
\hline
\end{tabular}

Uncertainties are quoted as standard deviation; bdl is below detection limit.

coating material and (ii) the time required to reach equilibrium activity concentrations, to use as a reference for other experiments. The test was performed at $18-24^{\circ} \mathrm{C}$ for about $100 \mathrm{~h} .{ }^{22} \mathrm{Rn}$ equilibrium values $\left(770 \pm 50 \mathrm{~Bq} \cdot \mathrm{m}^{-3}\right)$, much lower than the theoretical equilibrium, were reached in just two days, demonstrating that the room "breaths", exchanging air with the outdoor environment. ${ }^{20} \mathrm{Rn}$ equilibrium values $\left(523 \pm 203 \mathrm{~Bq} \cdot \mathrm{m}^{-3}\right)$ was attained earlier due to lower ${ }^{220} \mathrm{Rn}$ half-life, with marked fluctuations inversely correlated with temperature (Table 3 ).

In the second test, the side walls of the model room were externally covered with a transparent film used to conserve food in order to simulate the effect of an outer cover on ${ }^{222} \mathrm{Rn}$ and ${ }^{220} \mathrm{Rn}$ radon concentrations (Table 3 ). The test was performed at $20-26^{\circ} \mathrm{C}$. Equilibrium activity of ${ }^{222} \mathrm{Rn}(10623 \pm$ $137 \mathrm{~Bq} \cdot \mathrm{m}^{-3}$ ) was achieved in $\sim 100 \mathrm{~h}$, demonstrating that the model room is more isolated than before and ${ }^{222} \mathrm{Rn}$ flux out of the room is strongly reduced. Equilibrium ${ }^{220} \mathrm{Rn}$ level $\left(530 \pm 124 \mathrm{~Bq} \cdot \mathrm{m}^{-3}\right)$ is not affected by this condition, because ${ }^{220} \mathrm{Rn}$, characterized by a much lower half-life, is scarcely affected by the reduction of air exchange induced in this test.

In the following test, in addition to the previous experimental arrangement, the inner walls of the room were covered with a radon-free plasterboard to investigate if the addition of a pervious internal shield could reduce indoor radon. The equilibrium value of ${ }^{222} \mathrm{Rn}$ increased by $20 \%\left(13154 \pm 211 \mathrm{~Bq} \cdot \mathrm{m}^{-3}\right)$, probably due to the experimental temperature $\left(25-31^{\circ} \mathrm{C}\right)$, which was about $18 \%$ higher than that in the previous experiment, since temperature is known to enhance gas release from rocks [3, 10]. We do not attribute this increase to the plasterboard, which was not a source of radon, as resulted from preliminary measurements. On the other hand, the equilibrium value of ${ }^{220} \mathrm{Rn}$ was almost halved $\left(230 \pm 103 \mathrm{~Bq} \cdot \mathrm{m}^{-3}\right)$ because the inner cover, though permeable, made longer the time required for gas release through it, with a consequent decay.

In the fourth test, keeping the same experimental configuration of test 3 , a double coat of a simple thermal insulation paint was added on the inner plasterboard to verify the shielding effect of this paint. The equilibrium value of ${ }^{222} \mathrm{Rn}$ slightly decreased by $8 \%\left(12145 \pm 227 \mathrm{~Bq} \cdot \mathrm{m}^{-3}\right)$, while that of ${ }^{220} \mathrm{Rn}$ was strongly cut down and below detection limit (Table 3), demonstrating that this coating is somewhat pervious to gas, with a very limited effect on ${ }^{222} \mathrm{Rn}$ but a drastic influence on the shortest-lived ${ }^{220} \mathrm{Rn}$.

A waterproofing paint was internally added over the thermal insulation paint of experiment 4 (experi- ment 5a in Table 3). The effect of this further coating slightly reduced (by a further 9\%) the equilibrium ${ }^{222} \mathrm{Rn}$ activity concentration at $11400 \pm 155 \mathrm{~Bq} \cdot \mathrm{m}^{-3}$. ${ }^{220} \mathrm{Rn}$ levels continued to be negligible (below detection limit). These data confirmed that inner coats of pervious paints have a negligible influence on ${ }^{222} \mathrm{Rn}$, while are very effective for ${ }^{220} \mathrm{Rn}$.

At the end of this test (experiment 5b in Table 3), the outer plastic film was removed to evaluate radon levels with internal pervious shields (the plasterboard and two kinds of common paint), without the external protection. ${ }^{222} \mathrm{Rn}$ levels abruptly reached $1040 \pm$ $71 \mathrm{~Bq} \cdot \mathrm{m}^{-3}$, approaching values of test 1 . The unexpected slightly higher activity concentration of this experiment compared to that of test 1 is probably due to the higher experimental temperature of experiment $5\left(23-27^{\circ} \mathrm{C}\right)$ with reference to the other $\left(18-24^{\circ} \mathrm{C}\right)$. Conversely, ${ }^{220} \mathrm{Rn}$ was not affected at all. This demonstrated that this nuclide is mostly affected by inner shielding rather than outer covers.

\section{Conclusions}

This set of data shows that the scale model room is very useful to assess the effects of inner and outer covers on ${ }^{222} \mathrm{Rn}$ and ${ }^{220} \mathrm{Rn}$ levels. These experiments were not intended to obtain realistic activity concentration values because the model is different from a real room. Actually, its reduced volume and different temperature, humidity and pressure gradients affect the radon exhalation of "Tufo di Gallese" ignimbrite and its exchange with the outdoor air. Nevertheless, these measurements suggest that the high indoor ${ }^{222} \mathrm{Rn}$ concentration recorded in buildings of Caprarola could be considerably lowered, removing insulating external covers (i.e. plaster, etc.) and leaving tuff bricks exposed. ${ }^{220} \mathrm{Rn}$ levels could be drastically cut, just covering the inner walls with plasterboard, paints or wallpaper. A direct dependence of exhalation on temperature was observed too.

The next step will be (i) to monitor temperature, humidity and pressure gradients between the model room and the outdoor environment to evaluate their influence on radon levels and (ii) to investigate how different indoor/outdoor pressure gradients affect equilibrium radon activities and promote the usage of this practice (pressurization vs. depressurization of indoor environments) in radon remediation.

Acknowledgments. This research was accomplished in the frame of RESPIRE, a LIFE 2016 project funded 
by the European Commission. The grant to Department of Science, Roma Tre University (MIUR - Italy Dipartimento di Eccellenza, Articolo 1, Commi 314 337 Legge 232/2016) is also gratefully acknowledged. Francesca Sabino helped in the determination of total gamma radiation of soil samples from the Caprarola area.

\section{ORCID}

P. Tuccimei (D) http://orcid.org/0000-0001-8601-8313

\section{References}

1. National Council on Radiation Protection and Measurements. (2009). Ionizing radiation exposure of the population of the United States. Bethesda, MD: NCRP. (Report no. 160).

2. Bruno, R. C. (1983). Sources of indoor radon in houses: A review. Journal of the Air Pollution Control Association, 33(2), 105-109. DOI: 10.1080/00022470.1983.10465550.

3. Ruggiero, L., Bigi, S., Ciotoli, G., Galli, G., Giustini, F., Lombardi, S., Lucchetti, C., Pizzino, L., Sciarra, A., Sirianni, P., Tartarello, M. C., \& Voltaggio, M. (2018). Relationships between geogenic radon potential and gamma ray maps with indoor radon levels at Caprarola municipality (central Italy). In GARMM - 14 . International Workshop on the Geological Aspects of Radon Risk Mapping, 18-20 September 2018, Prague, Czech Republic. (extended abstract).

4. Tuccimei, P., Castelluccio, M., Soligo, M., \& Moroni, M. (2009). Radon exhalation rates of building materials: experimental, analytical protocol and classification criteria. In D. N. Cornejo \& J. L. Haro (Eds.), Building materials: Properties, performance and applications (pp. 259-273). Hauppauge, NY: Nova Science Publishers.

5. Lucchetti, C., Briganti, A., Castelluccio, M., Galli, G., Santilli, S., Soligo, M., \& Tuccimei, P. (2019). Integrating radon and thoron flux data with gamma radiation mapping in radon-prone areas. The case of volcanic outcrops in a highly-urbanized city (Roma, Italy). J. Environ. Radioact., 202, 41-50. DOI: 10.1016/j.jenvrad.2019.02.004.

6. Tuccimei, P., Moroni, M., \& Norcia, D. (2006). Simultaneous determination of ${ }^{222} \mathrm{Rn}$ and ${ }^{220} \mathrm{Rn}$ exhalation rates from building materials used in Central Italy with accumulation chambers and a continuous solid state alpha detector: influence of particle size, humidity and precursors concentration. Appl. Radiat. Isot., 64(2), 254-263.

7. Wiegand, J. (2001). A guideline for the evaluation of the soil radon potential based on geogenic and anthropogenic parameters. Environ. Geol., 40, 949-963.

8. Scarciglia, F., Tuccimei, P., Vacca, A., Barca, D., Pulice, I., Salzano, R., \& Soligo, M. (2011). Soil genesis, morphodynamic processes and chronological implications in two soil transects of SE Sardinia, Italy: traditional pedological study coupled with laser ablation ICP-MS and radionuclide analyses. Geoderma, 162, 39-64. DOI: 10.1016/j.geoderma.2011.01.004.

9. De Simone, G., Lucchetti, C., Galli, G., \& Tuccimei, P. (2016). Correcting for $\mathrm{H}_{2} \mathrm{O}$ interference using electrostatic collection-based silicon detectors. J. Environ. Radioact., 162/163, 146-153. DOI: 10.1016/j. jenvrad.2016.05.021.

10. Tuccimei, P., Castelluccio, M., Moretti, S., Mollo, S., Vinciguerra, S., \& Scarlato, P. (2011). Thermal enhancement of radon emission from rocks. Implications for laboratory experiments under increasing deformation. In B. Veress \& J. Szigethy (Eds.), Horizons in earth science research (Vol. 4, Chapter 9, pp. 247-256). Hauppauge, NY: Nova Science Publishers. 